\title{
VARIASI KELUASAN MAKNA TEKSTUAL (KMT) DALAM TEKS DWIBAHASA FIVE ON THE TREASURE DAN LIMA SEKAWAN DI PULAU HARTA
}

\author{
Devi Rosmawati ${ }^{1)}$, Asruddin Barori Tou ${ }^{2)}$ \\ Universitas Respati Yogyakarta ${ }^{1)}$, Universitas Negeri Yogyakarta ${ }^{2)}$ \\ dv_rose2711@yahoo.com ${ }^{1)}$, asruddintou@yahoo.com ${ }^{2)}$
}

\begin{abstract}
Abstrak
Penelitian ini bertujuan untuk mendeskripsikan variasi keluasan makna tekstusal (KMT) yang direpresentasikan dalam teks Five on The Treasure Island dan Lima Sekawan di Pulau Harta, mendeskripsikan makna variasi KMT tersebut dalam konteks penerjemahan, serta membahas dan menginterpretasikan faktor-faktor kontekstual yang memotivasi terjadinya variasi KMT. Jenis penelitian ini adalah deskriptif-kualitatif yang menerapkan kerangka teoritik Translation Tou dan model komunikasi sematik translational untuk analisis translasi dan model conceptual Halliday untuk analisis makna tekstual. Sumber data yang digunakan adalah dua novel dengan fokus pada satuan-satuan klausa. yang mewujudkan satuan-satuan makna tekstual. Instrumen penelitian ini adalah peneliti sendiri dengan menerapkan konsep Komunikasi Semiotik Translasional (KST) dan konsep Halliday tentang makna tekstual. Pengujian keabsahan data dilakukan melalui triangulasi. Hasil penelitian menunjukkan bahwa variasi KMT antara $\mathrm{T} 1$ dan $\mathrm{T} 2$ cenderung sangat rendah atau $\mathrm{T} 1=\mathrm{T} 2$, hal ini dapat dilihat dari tingkat frekuensi kemunculan terdapat pada variasi nol atau sangat rendah sebesar 552 atau $63,52 \%(\mathrm{~T} 1=\mathrm{T} 2)$. Berdasarkan hasil rerata tingkat keluasannya, T1 lebih luas dari T2. Hal ini dapat dilihat dari kemunculan rerata $\mathrm{T} 1$ sejumlah 193 atau sebesar 22,21\%. Jenis-jenis tema yang memotivasi terjadinya variasi keluasan makna tekstual yaitu: tema interpersonal, tema tekstual, dan tema topikal. Faktor-faktor kontekstual yang memotivasi terjadinya variasi KMT, yaitu konteks situasi dan konteks budaya. Konteks situasi terdiri dari field, tenor dan mode. Konteks budaya ditunjukkan oleh istilah yang mengacu pada budaya T1 digunakan pada T2. Pada judul yang tampak pada T1 dan $\mathrm{T} 2$, mengindikasikan bahwa $\mathrm{T} 2$ berintertekstual dengan $\mathrm{T} 1$.
\end{abstract}

Kata Kunci: penerjemahan, tema-rema, keluasan makna tekstual.

\section{THE TEXTUAL MEANING BREADTH VARIATION OF THE FIVE ON THE TREASURE ISLAND AND LIMA SEKA WAN DI PULAU HARTA.}

\begin{abstract}
The study aims are to describing the variation of textual meaning breadth (TMB) on "Five on The Treasure Island" and "Lima Sekawan Di Pulau Harta", to describe the meaning of TMB in translational context, to interpret the contextual factors that cause the variation conceptual model of the $T M B$. This was a descriptive-qualitative research which applied Tou's Translation framework and Translation sematic Communication model of translation analysis and halliday's conceptual model of textual meaning analysis. The data sources were two novels with the focus on the clause units. The instrumens were the researcher herself and the observations sheets. The validity was achieved through triangulation. The results of this research indicate that the dominant variation of $T 1$ and $T 2$ is very low $(T 1=T 2)$. It is supported by the highest figure of the zero variation which is 552 or $63,52 \%$, the most prominent mean of two texts which is on T1. It can be seen from score 193 or 22,21\%. There are kinds of themes that motivate the TMB. Kinds of themes that motivate the TMB variations are: interpersonal theme, textual theme, and topical theme. Contextual factors that motivate the textual meaning breadth of the two texts are situational context and cultural context. In short, situational context consist of field, tenor, and mode. Cultural context can be seen from the cultural terms in T1 used in T2. From the titles that appear in T1 and T2, it indicates that T2 intertextualizes with T1.
\end{abstract}

Keywords: translation, theme-rheme, textual meaning breadth. 


\section{PENDAHULUAN}

Banyak novel asing yang telah diterjemahkan kedalam bahasa Indonesia. Berkaitan dengan hal tersebut dapat dikatakan bahwa telah terjadi proses penerjemahan guna memindahkan bahasa asing tersebut ke dalam bahasa Indonesia. Dalam proses penerjemahan membutuhkan seorang penerjemah untuk mengalihbahasakan novel-novel tersebut. Dalam hal ini penerjemah tidak hanya memindahkan bahasa sumber ke bahasa sasaran akan tetapi makna atau pesan yang terdapat dalam bahasa sumber haruslah tersampaikan ke dalam bahasa sasaran.

Terkait dengan pemindahan pesan atau makna tersebut, terdapat beberapa makna yang terdapat dalam sebuah teks. Makna-makna tersebut dalam konsep sistemik fungsional yaitu makna interpersonal, makna ideasional, dan makna tekstual. Pada makna tekstual, teks berkaitan dengan penciptaan teks. Dalam penciptaan teks pasti penulis memiliki maksud dan tujuan. Ketika menyusun sebuah teks, hal tersebut bukanlah hanya semata-mata bentuk dari kata, frasa, klausa/kalimat yang menjadi fokus dalam teks tersebut, akan tetapi makna atau pesanlah yang ingin dihadirkan.

Untuk mengukur berapa derajat suatu makna, dapat dilihat berdasarkan ketinggian, kedalaman, serta keluasan dari makna tersebut. Dalam penelitian ini, peneliti akan memfokuskan pada (1) variasi keluasan makna tekstual dalam teks dwibahasa Five on The Treasure Island karya Enid Blyton dan Lima Sekawan Di Pulau Harta karya Agus Setiadi, (2) makna dari variasi keluasan tersebut, (3) faktor-faktor kontekstual yang menimbulkan terjadinya variasi keluasan makna tekstual (KMT) kedua teks tersebut.

Tujuan dari penelitian ini adalah: (1) mendeskripsikan variasi keluasan makna tekstual yang direpresentasikan dalam teks dwibahasa Five on The Treasure Island karya Enid Blyton dan Lima Sekawan di Pulau Harta karya Agus Setiadi, (2) mendeskripsikan makna variasi keluasan makna tekstual tersebut dalam konteks penerjemahan berdasarkan rerata antara teks bahasa sumber (T1) dan teks bahasa sasaran (T2), (3) membahas dan menginterpretasikan faktor-faktor kontekstual yang memotivasi terjadinya variasi keluasan makna tekstual.

\section{Teori yang Relevan}

\section{Teori Penerjemahan}

Catford (1965, p.1) mengatakan bahwa "penerjemahan merupakan sebuah proses perubahan teks dalam satu bahasa dengan teks bahasa lain, penerjemahan harus menggunakan teori bahasa dan teori linguistik umum".

Penerjemahan menurut Nida dan Taber (1982, p.12) adalah "proses untuk menghasilkan padanan alami yang paling mendekati dari pesan bahasa sumber ke dalam bahasa penerima, pertama pada tingkat makna dan kedua pada tingkat gaya".

Kata penerjemahan menurut (Nababan, 2008, p.18)) mengandung pengertian proses alih pesan, akan tetapikata terjemahan artinya hasil dari suatu penerjemahan. Istilah translation mengacu pada pengalihan pesan tertulis, akan tetapiinterpretation mengacu hanya pada pengalihan bahasa lisan.

Brislin (melalui Choliludin, 2005, p.18) mendefinisikan bahwa "translasi adalah istilah umum yang mengacu pada pemindahan pikiran dan gagasan dari satu bahasa sumber kebahasa lainnya (sasaran), apakah bahasa tersebut dalam bentuk bahasa lisan ataupun bentuk tulisan."

Dari definisi keseluruhan di atas, dapat ditarik kesimpulan bahwa inti dari penerjemahan yaitu: (1) pemindahan suatu bentuk pesan ke bentuk yang lain dengan isi pesan yang sama, (2) penerjemahan bukan sekedar melibatkan bahasa (verbal), karena segala tanda atau wujud representasi makna tidak hanya bahasa. Sebagai contoh menerjemahkan keindahan alam/ lukisan melalui puisi, menerjemahkan perasaan seseorang melalui lagu.

\section{Jenis-jenis Penerjemahan}

Jakobson, seorang linguist Rusia-Amerika membuat tiga jenis penerjemahan tulis (Hatim,2004, p.5) yaitu antara lain: (1) Intralingual translation, yaitu penerjemahan dengan menggunakan bahasa yang sama, diubah/diterjemahkan dengan paraphrase atau rewording. Bahasa yang terlibat pada jenis penerjemahan ini hanya terdapat satu bahasa. Sebagai contoh: membuat simplifikasi novel, memparafrasakan sebuah puisi. Pada contoh tersebut bahasa yang digunakan hanya satu(monolingual). (2) Interlingual translation, yaitu penerjemahan dari satu bahasa ke bahasa lain(bilingual/multilingual). Jenis penerjemahan ini sering dilakukan pada novel, buku, film. Pada film, bahasa pengantar yang terdapat pada film akan diganti dengan 
bahasa lain(dubbing). (3) Intersemiotic translation, yaitu penerjemahan dengan menggunakan tanda verbal dari tanda non-verbal. Jenis penerjemahan ini dapat kita lihat pada kegiatan menganalisis atau memahami sebuah gambar/ lukisan, dan membaca pesan lampu lalu lintas.

Menurut konsep kebahasaan semiotik translational (KST) penerjemahan pada umumnya dipahami sebagai proses pemindahan makna dari satu bahasa ke bahasa lain. Dalam konsep komunikasi semiotik translasional (KST), penerjemahan merupakan fenomena yang terdiri dari tiga kajian yaitu penerjemahan intra-kebahasaan ekabahasa, singkatnya KST kebahasaan ekabahasa atau lebih singkat lagi KST ekabahasa, penerjemahan lintas-kebahasaan multibahasa, singkatnya KST multibahasa, penerjemahan dwibahasa atau lebih singkat lagi KST dwibahasa.

KST kebahasaan multibahasa adalah KST kebahasaan yang melibatkan tiga atau lebih bahasa sebagai perealisasinya. KST kebahasaan dwibahasa adalah KST kebahasaan yang melibatkan dua bahasa sebagai perealisasinya, sementara KST kebahasaan ekabahasa adalah KST kebahasaan yang pada jenjang semiotik denotatif/tekstual melibatkan satu bahasa sebagai perealisasinya. Semua tindak penerjemahan tersebut dilakukan oleh penerjemah secara simultan (bersamaan) atau non simultan (tidak bersamaan).

Dalam penerjemahan perlu adanya seorang penerjemah dalam proses memindahkan bahasa sumber ke bahasa sasaran. Seorang penerjemah tidak hanya bertugas memindahkan makna bahasa sumber ke bahasa sasaran semata, tetapi juga turut memindahkan pesan bahasa sumber ke bahasa sasaran. Selain itu, pemahaman sistem kebahasaan, konteks budaya serta konteks situasi juga merupakan syarat penerjemah dalam mengalihbahasakan teks sumber ke teks sasaran. Dengan demikian pesan yang disampaikan oleh penulis akan sampai ke pembaca sasaran.

\section{Teori Makna}

Menurut Halliday bahasa yaitu sebagai sumber untuk mengungkap makna. Bahasa merupakan suatu sistem makna, yang dilengkapi dengan bentuk-bentuk yang digunakan untuk mewujudkan makna itu. Teorinya yang dikenal dengan Systemic functional linguistics (SFL) tidak lain adalah teori makna sebagai pilihan. Artinya, teori sistemik bahasa ini merupakan teori pilihan pada makna dan menjadi sarana untuk menafsirkan serangkaian pilihan-pilihan pengungkapan makna dalam bentuk teks (Halliday, 2004, p.xiv).

Teks merupakan istilah ucapan/tulisan seseorang. Teks tersebut mengacau pada bahasa apapun. Bahasa selalu hadir sebagai teks. Teks bukanlah semata-mata bentuk kata atau kalimat. Ketika kita menyusun teks, bukanlah kata-kata atau kalimat yang menjadi fokus kita, melainkan makna yang ingin kita hadirkan melaluinya. Jadi, wujud kata dan kalimat itu ditentukan oleh makna-makna yang menjadi fokus dari teks itu (Halliday \& Matthiessen, 2004, p.3).

\section{Jenis-jenis Makna}

Halliday (2004, pp.29-30) menjelaskan bahwa apa yang dialami manusia disediakanlah bahasa untuk mengungkapkannya. Bahasa ini memiliki beberapa jenis makna untuk mengungkapkan fungsi dari bahasa tersebut. Makna tersebut antara lain makna ideasional, makna interpersonal, dan makna tekstual.

\section{Makna Ideasional}

Makna/fungsi ideasional merupakan makna yang terkait dengan pengalaman. Makna tersebut diperoleh manusia melalui pengalaman hidupnya. Halliday menyebutnya dengan makna experiential. Pengalaman manusia direalisasikan dalam bentuk kata yang disusun menjadi kalimat yang mempunyai makna yang utuh. Susunan tersebut diubah menjadi paragraph yang memberikan informasi dan diungkapkan melalui tulisan maupun bahasa lisan. Salah sistem gramatikal makna ideasional yang utama yaitu transitifitas(transitivity) atau sumber untuk menafsirkan pengalaman dan timbul tenggelamnya suatu peristiwa. Masing-masing peristiwa tersebut terdiri dari proses, partisipan, dan keadaan. Misalnya; 'In the open glade(lokasi), the wild rabbits(pelaku), danced(proses), with their shadows(keterangan), (Halliday dalam Choliludin 2005, p.36).

Menurut Hatim (2004, pp.341-342) menjelaskan makna ideasional menyerupai dengan yang dipaparkan Halliday yaitu sebagai berikut:

Ideational meaning language used to convey information, ideas or experience. It is a means of giving structure to our experience of inner feelings and emotions as well as of the external world around us.

Makna ideasional digunakan untuk menyampaikan informasi, ide atau pengalaman, hal ini dengan kata lain dimaksudkan untuk mem- 
berikan struktur terhadap pengalaman batin dan emosi sebagaimana dengan keadaan luar sekitar kita.

\section{Makna Interpersonal}

Hatim dan Munday (2004, p.343) menjelaskan bahwa dalam makna interpersonal berkenaan dengan membina hubungan antara penghasil teks dan penerima teks interpersonal meaning to established a relationship between text producer and text receiver.

Makna interpersonal merupakan interpretasi bahasa yang fungsinya sebagai pertukaran (exchange) yang mewakili hubungan 'speech role'. Jadi apabila dua orang menggunakan bahasa untuk berinteraksi, salah satu yang mereka lakukan dalam interaksi tersebut membangun hubungan diantara keduanya, baik berfungsi (a) giving maupun (b) demanding, (Halliday dalam Sinar, 2007, p.78).

Akan tetapi untuk mengidentifikasi fungsi pertukaran tersebut, direalisasikan melalui struktur Mood. Mood berfungsi untuk mengungkapkan apakah sesuatu hal dapat dianggap bersifat deklaratif, interogatif, dan imperative atau indicative.

Aspek lain pada makna menurut Halliday (1994, p.68) dapat direalisasikan melalui klausa. Pada klausa ini terdapat makna yang dapat digunakan sebagai pertukaran 'exchange'. Hal inilah yang merupakan 'principal grammatical system' pada Mood.

\section{Makna Tekstual}

Makna tekstual terkait dengan penciptaan teks yang didasarkan pada konteks penciptaan teks. Penciptaan teks tidak serta merta diciptakan tanpa maksud dan tujuan. Fungsi tekstual pada suatu teks memiliki unsur tematik yaitu tema dan rema.
Tema dan rema tersebut dapat diperluas lagi untuk setiap klausa tunggal yang terdapat dalam teks. Struktur klausa di dalam klausa menurut teori LFS, ditentukan oleh konteks sosial sebagai bagian dari konteks situasi. Tema dan Rema merupakan unsur semiotik sosial di atas register, terdapat konteks budaya yang menjadi penentu cara. Dengan kata lain, budaya secara parsial atau keseluruhan menentukan struktur Tema dan Rema.

\section{Tema dan Rema}

Telah di bahas di atas bahwa dalam makna tekstual terdapat struktur tematik yang terdiri dari elemen tema dan rema. Halliday (1994, pp.37-38) menyatakan bahwa tema adalah "what the message is concerned with". Tema merupakan titik pandang si penutur/pembicara akan berkata mengenai apa sesuai dengan konteks. Rema merupakan apa yang dikatakan si penutur/pembicara mengenai tema. Rema dalam sebuah klausa merupakan elemen yang penting karena rema merepresentasikan pesan/informasi apa yang ingin disampaikan terhadap pendengar/ pembaca.

Pada satu unsur klausa kompleks, fungsi tema dalam satu klausa ditempati oleh sejumlah unsur yang masing-masing unsur memiliki fungsi tema yang berbeda yaitu tema Tekstual, tema interpersonal, dan Topikal, (Halliday, 2004, p.79).

Tabel Tema Tekstual, Interpersonal dan Topikal

\begin{tabular}{cc}
\hline & Continuative \\
Tekstual & Structural Conj. \\
& Conjunctive \\
& Modal/comment adj \\
Interpersonal & Vocative \\
Topikal & Finite verbal (yes/no) \\
Nominal (group)
\end{tabular}

Berikut ilustrasi ketiga tema tersebut :

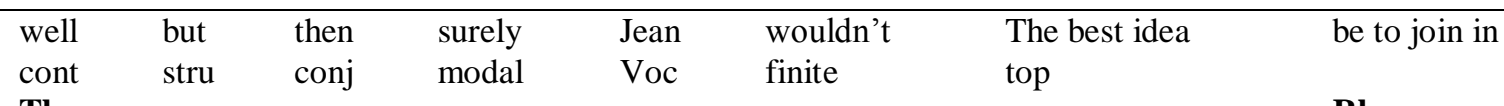

Theme Rheme

1. Tekstual (cont.): continuative merupakan elemen tema tessktual merupakan langkah/ ucapan baru untuk membicarakan pembicaraan berikutnya, misal; yes, well, oh, now.

2. Tekstual (stru) :conjunction merupakan kata/kelompok kata yang menyambungkan klausa paratactic ataupun hypotactic [paratactic] and, or, but,nor, neither, either, yet, so, then, for

[hypotactic] when, while, before, after, until, because, if, although, since, that, whether, to, by, with, despite, as, even, if in case, assuming that, so that, so as to, in order, to in the event that, in spite of, the fact that. 
3. Tekstual (conjtv): merupakan grup adverbial/frasa prepositional yang menghubungkan klausa ke teks berikutnya, secara semantic/maknawi mereka sama dengan structural conjunction.

4. Interpersonal (modal): this express the speaker or writer's judgement on/attitude to the content of the message.

5. Interpersonal (vocative): this is any item, typically a personal name, being used to address.

6. Interpersonal (finite): merupakan set kecil dari finite auxiliary verbs untuk menafsirkan tenses tertentu/modality.

[primary tense] am, is, are, was, were, do, does, did, have, has, had, shall, will

[modality] can, could, may, might, shall, should, will, must, ought.

\section{METODE}

\section{Jenis Penelitian}

Penelitian ini adalah penelitian deskriptif kualitatif dengan menggunakan menggunakan pendekatan analisis isi semantik.

\section{Waktu dan Tempat Penelitian}

Waktu penelitian dilakukan mulai bulan Juli 2012 - Mei 2013, tempat penelitian yaitu perpustkaan Universitas Negeri Yogyakarta, dan tempat tinggal peneliti.

\section{Sumber Data}

Sumber data penelitian ini berupa klausaklausa yang terdapat pada karya Five on The Treasure dan Lima Sekawan di Pulau Harta. Sumber data yaitu novel berjudul Five on The Treasure dan Lima Sekawan di Pulau Harta.

\section{Teknik Pengumpulan Data}

Pengumpulan data menggunakan teknik simak dan catat dengan proses sebagai berikut: (1) membaca dan membaca kembali isi keseluruhan novel, (2) mencatat atau menyalin data dengan cara menulis kembali teks sesuai dengan bahasa masing-masing, (3) mengelompokkan data yang berupa kalimat tersebut sesuai dengan teks sumber dan teks terjemahan pada kolom yang telah disediakan, (4) memeriksa kembali agar masing-masing teks sudah sesuai pada kolomnya.

\section{Teknik Analisis Data}

Setelah tahap pengumpulan data, tahapan yang berikut adalah menganalisis data dengan proses sebagai berikut: (1) menganalisis data yang berwujud klausa-klausa, kemudian memasukkan ke tabel berdasarkan jenis tema tekstual yang mencerminkan variasi KMT, (2) mengolah atau menghitung hasil analisis data tersebut menggunakan statistik deskriptif, (3) menjelaskan hasil pengolahan data berdasarkan frekuensi kemunculan serta tingkat keluasan, (4) menjelaskan faktor-faktor yang mendorong terjadinya tersebut, (4) menyimpulkan hasil penelitian.

\section{Parameter Variasi}

1. Variasi Nol (0): akan terjadi apabila terdapat elemen dan jenis tema sama, jumlah elemen sama.

2. Variasi satu (1): akan terjadi apabila terdapat perbedaan satu, dilihat dari elemen atau jenis tema dari kedua teks tersebut.

3. Variasi satu (2): akan terjadi apabila terdapat perbedaan dua dilihat dari elemen atau jenis tema dari kedua teks tersebut.

4. Variasi satu (3): akan terjadi apabila terdapat perbedaan tiga dilihat dari elemen atau jenis tema dari kedua teks tersebut.

5. Variasi satu (4): akan terjadi apabila terdapat perbedaan empat dilihat dari elemen atau jenis tema dari kedua teks tersebut.

\section{HASIL DAN PEMBAHASAN}

Berdasarkan analisis yang telah dilakukan, berikut merupakan hasil penelitian yang akan disajikan dalam tabel kemudian dideskripsikan dalam pembahasan yang disertai contohcontoh kalimat/klausa yang ditemukan dalam novel bilingual Five on The Treasure Island dan Lima Sekawan di Pulau Harta. Dalam bab ini akan dibahas kedua tujuan tersebut dengan membagi menjadi dua bagian yaitu mendeskripsikan hasil penelitian yang terdiri penemuan data yang akan direpresentasikan dengan angka dan persentase dan bagian yang kedua yaitu menjelaskan deskripsi tersebut dalam suatu pembahasan.

\section{Deskripsi Variasi Keluasan Makna Tekstual}

Untuk menganalisis variasi keluasan makna yang terdapat pada $\mathrm{T} 1$ dan $\mathrm{T} 2$, digunakan 869 unit data berwujud kalimat (klausa bebas). Pengelompokkan variasi bermula dari skor nol 
(0) hingga (4) dengan kategori sangat rendah, rendah, medium, tinggi dan sangat tinggi. berikut.

Hasil analisis dapat kita lihat pada tabel

\begin{tabular}{lccc}
\hline \multicolumn{1}{c}{ Variasi } & Skor & Frekuensi & Prosentase \\
\hline Sangat rendah & 0 & 552 & $63,52 \%$ \\
Rendah & 1 & 210 & $24,16 \%$ \\
Medium & 2 & 50 & $5,75 \%$ \\
Tinggi & 3 & 38 & $4,37 \%$ \\
Sangat Tinggi & 4 & 19 & $2,2 \%$ \\
TOTAL & & 869 & $100 \%$ \\
\hline
\end{tabular}

Berdasarkan tabel tersebut, frekuensi kemunculan tertinggi yaitu terdapat pada variasi sangat rendah atau skor nol (0) dengan frekuensi 552 atau $63,52 \%$. Frekuensi yang tinggi berikutnya yaitu terdapat pada variasi rendah (1) dengan frekuensi 210 atau 24,16\%. Berikutnya yaitu terdapat pada variasi medium dengan skor (2) sebesar 50 kali atau 5,75\%. Pada variasi tinggi (3) sebesar 38 kali atau 4,37\%. Dan pada variasi tinggi (4) sebesar 19 kali atau 2,2\%. Dapat disimpulkan bahwa variasi keluasan makna tekstual pada Novel Five on The Treasure Island dan Lima Sekawan Di Pulau Harta bervariasi sangat rendah dengan frekuensi kemunculan sebesar 552 atau 63,52\%.

\section{Deskripsi Rerata Tingkat Variasi Keluasan Makna Tekstual antara T1 dan T2}

Tingkat keluasan Makna tekstual pada analisis penelitian ini diberi kolom T1, T2, dan $\mathrm{T} 1=\mathrm{T} 2$. Kolom (T1) akan diberi tanda apabila variasi terbesar dari skor (1-4) terdapat pada teks bahasa Inggris (T1), kolom berikutnya yaitu (T2) yaitu apabila variasi terbesar dari skor (1-4) terdapat pada teks bahasa Indonesia (T2). Pada kolom $\mathrm{T} 1=\mathrm{T} 2$ yaitu apabila tidak terdapat variasi antara teks satu (T1) dan (T2) atau skor nol (0).

Deskripsi Variasi Tingkat Keluasan dapat kita lihat pada tabel berikut.

\begin{tabular}{ccc}
\hline $\begin{array}{c}\text { Rerata Tingkat Variasi } \\
\text { Keluasan Makna Tekstual } \\
\text { Antara T1-T2 }\end{array}$ & Frek & Prosentase \\
\hline$\sum \mathrm{T} 1$ & 193 & $22,21 \%$ \\
$\sum \mathrm{T} 2$ & 124 & $14,27 \%$ \\
$\sum \mathrm{T} 1=\mathrm{T} 2$ & 552 & 63,52 \\
TOTAL & 869 & $100 \%$ \\
\hline
\end{tabular}

Variasi Keluasan (0-4)

Variasi $\operatorname{Nol}(0)$

Variasi nol (0) terjadi apabila T1dan T2 memiliki jumlah tema yang sama, baik dengan elemen tema yang sama ataupun elemen tema berbeda. Berikut beberapa contoh data dengan variasi nol (0).

won't be able to go with you this year.

kali ini tidak bisa ikut dengan kalian.

aku dan ibu

Rema

Conj. \& Cont.

Tema

Pada klausa T1 terdapat satu elemen tema tekstual yaitu elemen conjunctive adjunct dan pada klausa di T2 terdapat satu elemen tema tekstual yaitu continuative. Walaupun jenis tema tekstual berbeda, akan tetapi klausa T1 dan T2 sama-sama memiliki satu elemen tema tekstual dan tema lainnya. Hal ini menyebabkan terjadinya variasi nol(0) karena memiliki jumlah elemen tema yang sama baik pada T1 maupun pada $\mathrm{T} 2$.

\begin{tabular}{ll}
\hline "No!" & said Anne. \\
"Belum," & sahut Anne \\
Continuative & \\
Tema & Rema \\
\hline
\end{tabular}

Pada klausa di atas, T1 dan T2 sama-sama memiliki satu elemen tema tekstual yaitu elemen continuative. Hal ini memberikan dampak terjadinya variasi nol(0) karena memiliki jumlah elemen tema yang sama, baik pada T1 maupun pada $\mathrm{T} 2$.

\begin{tabular}{|c|c|c|c|c|}
\hline \multirow[t]{3}{*}{3} & T1 & Can & $w e^{\prime}$ & go to Polseath as usual?" \\
\hline & $\mathrm{T} 2$ & Bisakah & kita & $\begin{array}{l}\text { pergi ke Polseath, seperti } \\
\text { biasanya?" }\end{array}$ \\
\hline & & Tema & & Rema \\
\hline
\end{tabular}

Pada klausa di atas, T1 dan T2 sama-sama memiliki dua elemen tema. Hal ini memberikan dampak terjadinya variasi nol (0) karena memiliki jumlah elemen tema yang sama, baik pada $\mathrm{T} 1$ maupun pada $\mathrm{T} 2$. 


\begin{tabular}{cccl}
\hline 37 & T1 & He & lived by the sea \\
& T2 & Paman & tinggal di tepi laut. \\
& & Quentin & \\
& & Tema & Rema \\
38 & T1 & but & was about all that the children \\
& & that & knew of him! \\
& T2 & Cuma & yang diketahui anak-anak \\
& & itulah & tentang paman mereka itu. \\
& & Stru & \\
& & Tema & Rema \\
& & &
\end{tabular}

Pada keseluruhan klausa di atas, T1 dan T2 sama-sama memiliki tiga elemen tema. Hal ini memberikan dampak terjadinya variasi nol(0) karena memiliki jumlah elemen tema yang sama, baik pada $\mathrm{T} 1$ maupun pada $\mathrm{T} 2$.

\begin{tabular}{|c|c|c|c|}
\hline \multirow[t]{3}{*}{1} & $\mathrm{~T} 1$ & "MOTHER, & $\begin{array}{l}\text { have you heard about our } \\
\text { summer holidays yet?" }\end{array}$ \\
\hline & $\mathrm{T} 2$ & $\begin{array}{l}\text { "Bagaimana } \\
\text { | bu }\end{array}$ & $\begin{array}{ll}\text { sudah ada } & \text { tentang liburan } \\
\text { kabar } & \text { kita?" }\end{array}$ \\
\hline & & Tema & Rema \\
\hline \multirow[t]{2}{*}{2} & T1 & said & $\begin{array}{l}\text { Julian, at the breakfast- } \\
\text { table. }\end{array}$ \\
\hline & $\mathrm{T} 2$ & $\begin{array}{l}\text { tanya } \\
\text { Tema }\end{array}$ & $\begin{array}{l}\text { Julian pada suatu pagi } \\
\text { Rema }\end{array}$ \\
\hline
\end{tabular}

Variasi Satu (1)

Pada klausa kolom pertama, T1 hanya memiliki satu elemen tema, akan tetapi T2 memiliki dua elemen tema, jadi keseluruhan klausa di atas menyebabkan variasi satu (1).

Aunt Fanny
Bibi Fanny
Tema
and
dan biar bagaimanapun
Structural
Tema

Pada klausa kedua di atas T1 memiliki satu elemen tema tekstual yaitu elemen Structural Conjunction, akan tetapi di T2 terdapat dua elemen tema tekstual yaitu structural conjunction dan Conjunctive. Hal ini memberikan dampak terjadinya variasi satu (1) karena jumlah elemen pada $\mathrm{T} 1$ dan $\mathrm{T} 2$ berbeda satu (1), dengan $\mathrm{T} 2>\mathrm{T} 1$.

\begin{tabular}{lcl}
\hline 72 & And she & will love looking after you all. \\
Bibi & merasa senang dititipi kalian. \\
Structural & Rema \\
Tema & \\
\hline
\end{tabular}

Pada klausa di atas, T1 memiliki satu elemen tema tekstual yaitu elemen Structural Conjunction, akan tetapipada klausa di T2 tidak terdapat elemen tema tekstual. Hal ini menyebabkan adanya variasi satu(1) karena jumlah elemen pada $\mathrm{T} 1$ dan $\mathrm{T} 2$ berbeda satu, dengan $\mathrm{T} 1>\mathrm{T} 2$.

\section{Variasi Dua}

Variasi dua (2) akan timbul jika jumlah elemen pada T1 dan T2 berbeda dua. Berikut beberapa sampel data dengan variasi dua (2). has lived there all her life,

dilahirkan di sana,

Rema

wouldn't leave it for anything."

takkan mau pergi dari sana."

\section{Rema}

\begin{tabular}{|c|c|c|c|}
\hline \multirow[t]{3}{*}{235} & $\mathrm{~T} 2$ & $\begin{array}{l}\text { So her } \\
\text { mother } \\
\text {--- Ibu }\end{array}$ & $\begin{array}{l}\text { handed her some } \\
\text { chocolate, } \\
\text { memberikan beberapa } \\
\text { batang cokelat. }\end{array}$ \\
\hline & & Structural & \\
\hline & & Tema & Rema \\
\hline \multirow[t]{3}{*}{236} & $\mathrm{~T} 1$ & $\begin{array}{l}\text { and she and } \\
\text { the boys }\end{array}$ & $\begin{array}{l}\text { munched happily, } \\
\text { watching the hills, woods } \\
\text { and fields as the car sped } \\
\text { by. }\end{array}$ \\
\hline & $\mathrm{T} 2$ & $\begin{array}{l}\text {---Anne } \\
\text { bersama } \\
\text { kedua } \\
\text { saudara } \\
\text { laki-lakinya } \\
\text { Structural }\end{array}$ & $\begin{array}{l}\text { makan cokelat dengan } \\
\text { nikmat, sambil } \\
\text { mengarahkan perhatian, } \\
\text { ke pemandangan yang } \\
\text { dilewati. }\end{array}$ \\
\hline & & Tema & Rema \\
\hline
\end{tabular}

Pada klausa pertama dan kedua di atas, T1 memiliki dua elemen tema tekstual yaitu elemen Structural dan Continuative, akan tetapipada T2 tidak terdapat elemen tema tekstual . Hal ini memberikan dampak terjadinya variasi dua (2) karena jumlah elemen pada $\mathrm{T} 1$ dan $\mathrm{T} 2$ berbeda dua, dengan $\mathrm{T} 1>\mathrm{T} 2$. 


\begin{tabular}{ll}
\hline 95 "Oh & do telephone to Aunt Fanny \\
-- & telepon Bibi Fanny, \\
Continuative & Rema \\
Tema & ask her \\
and & tanyakan \\
dan & Rema \\
Structural & can go there!" cried Dick. \\
Tema & bisa ke sana!" seru Dick tak \\
if & sabar lagi. \\
--- & Rema \\
Structural & \\
Tema & \\
\hline
\end{tabular}

Pada klausa pertama dan ketiga, T1 memiliki satu elemen tema tekstual yaitu elemen Continuative dan Structural, akan tetapipada T2 tidak terdapat elemen tema tekstual. Hal ini memberikan dampak terjadinya variasi dua (2) karena jumlah elemen pada $\mathrm{T} 1$ dan $\mathrm{T} 2$ berbeda dua, dengan $\mathrm{T} 1>\mathrm{T} 2$.

Variasi Tiga (3)

\begin{tabular}{lll}
\hline 100 & It & sounds sort of adventurous!" \\
& Kedengaran & seperti banyak petualangan \\
& Tema & Rema \\
101 & --- Yang kita & --- \\
& & bisa dialami di sana!" \\
& $\begin{array}{l}\text { Structural } \\
\text { Tema }\end{array}$ & Rema \\
\hline
\end{tabular}

Pada klausa di atas, T1 tidak memiliki dua elemen tema dan satu elemen rema. Hal ini memberikan dampak terjadinya variasi tiga (3) karena jumlah elemen pada $\mathrm{T} 1$ dan $\mathrm{T} 2$ berbeda tiga, dengan $\mathrm{T} 2>\mathrm{T} 1$.

\begin{tabular}{|c|c|c|c|}
\hline \multirow[t]{2}{*}{237} & Mereka & \multicolumn{2}{|c|}{$\begin{array}{l}\text { berpiknik di puncak sebuah } \\
\text { bukit, di tengah lapangan yang } \\
\text { melandai ke arah sebuah } \\
\text { lembah. }\end{array}$} \\
\hline & Tema & \multicolumn{2}{|c|}{ Rema } \\
\hline \multirow{2}{*}{238} & $\begin{array}{l}\text { Bukit, } \\
\text { hutan, dan } \\
\text { tanah } \\
\text { pertanian } \\
\text { silih } \\
\text { berganti }\end{array}$ & \multicolumn{2}{|c|}{ terlihat. } \\
\hline & Tema & & Rema \\
\hline \multirow[t]{2}{*}{239} & Lembah itu & \multirow[t]{2}{*}{ that } & $\begin{array}{l}\text { looked down into a } \\
\text { sunny valley. } \\
\text { nampak cerah kena sinar } \\
\text { matahari. }\end{array}$ \\
\hline & Tema & & Rema \\
\hline
\end{tabular}

Pada klausa di atas, T1 tidak memiliki dua elemen tema dan satu elemen rema. Hal ini memberikan dampak terjadinya variasi tiga (3) karena jumlah elemen pada $\mathrm{T} 1$ dan $\mathrm{T} 2$ berbeda tiga, dengan T2 $>\mathrm{T} 1$.

$\begin{array}{lll}415 & --- & --- \\ & \text { Padahal dia } & \text { akan sekamar denganku } \\ & \text { Tema } & \text { Rema }\end{array}$

Pada klausa di atas, T1 tidak memiliki dua elemen tema dan satu elemen rema. Hal ini memberikan dampak terjadinya variasi tiga (3) karena jumlah elemen pada $\mathrm{T} 1$ dan $\mathrm{T} 2$ berbeda tiga, dengan T2>T1.

Variasi Empat (4)

\begin{tabular}{lll}
\hline 202 & --- & --- \\
& Dan & tidak enak bukan, \\
Structural & \\
Tema & Rema \\
--- & --- \\
jika & bermain-main di alam yang \\
& Suram? \\
Structural & \multicolumn{2}{c}{ Rema } \\
\hline
\end{tabular}

Pada kedua klausa di atas, T1 tidak terdapat unsur tematik (tema dan rema), akan tetapipada T2 terdapat unsur tematik (tema dan rema). Hal ini menyebabkan adanya variasi perbedaan dengan skor empat(4), dengan $\mathrm{T} 2>\mathrm{T} 1$.

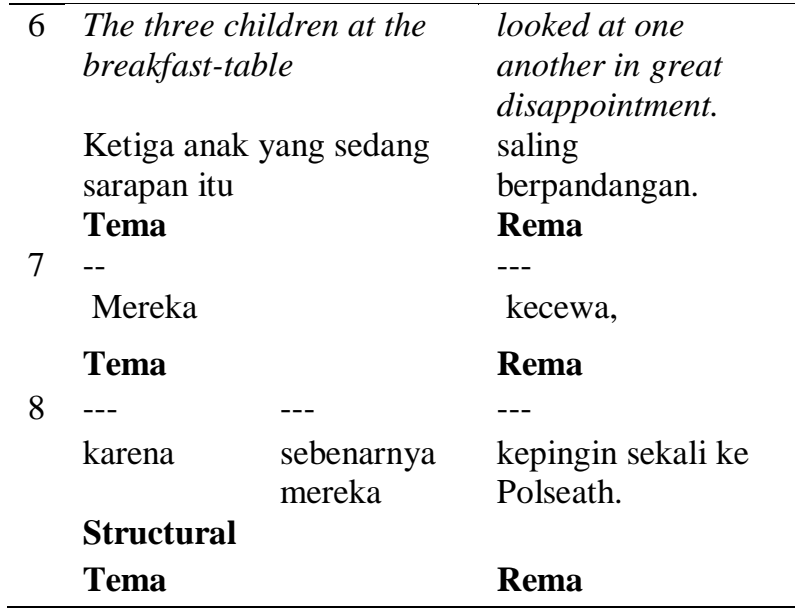

Pada klausa kedua dan ketiga di atas, T1 tidak terdapat unsur tematik (tema dan rema), akan tetapipada T2 terdapat unsur tematik (tema dan rema). Hal ini menyebabkan adanya variasi perbedaan dengan skor empat(4), dengan $\mathrm{T} 2>\mathrm{T} 1$. 


\section{Faktor Kontekstual}

Konteks Situasional

Sebagaimana telah dibahas sebelumnya, bahwa secara kontekstual bahasa terikat kepada konteks. Konteks dipengaruhi oleh teks. Apabila seorang menganalisis teks secara vertical ke bawah, ini berarti teks dianalisis berdasarkan variabel linguistik (klausa, kata, morfem, grafem, dst). Sebaliknya, apabila teks dianalisis secara vertical ke atas berarti teks dilihat dari variabel kontekstual yaitu konteks situasi, budaya, inter-intra teks. Untuk memahami teks, seseorang harus terbiasa dengan ciri konteks situasi, yaitu konteks yang memiliki teks yang mengungkapkan dan memiliki lingkungan tempat makna itu dipertukarkan.

Tiga konteks situasi novel Five on The Treasure Island dan Lima Sekawan Di Pulau Harta yaitu sebagai berikut:

Field

Field yaitu mengacu pada 'apa yang sedang terjadi'. Pada novel bahasa Inggris Five on The Treasure Island mengisahkan tiga bersaudara yaitu Julian,Anne, Dick serta sepupu mereka bernama Georgina dan anjingnya Tim. Mereka berlima terlibat dalam kisah petualangan yang menarik. Cerita berawal pada waktu Julian, Anne, dan Dick berencana akan melakukan liburan di Polseath akan tetapi ternyata disana penuh, dan pada akhirnya mereka berlibur di rumah paman dan bibi mereka di Teluk Kirrin. Anak paman dan bibi, yaitu sepupu mereka yang bernama Georgina mengatakan bahwa ia memiliki sebuah pulau yaitu Pulau Kirrin. Disanalah kisah cerita petualangan mereka bermula. Pada teks novel bahasa Indonesia juga menceritakan field yang sama dengan teks bahasa Inggris (T1).

Tenor

Tenor merupakan istilah untuk hubungan antara orang-orang yang ikut andil dalam suatu cerita/ pembicaraan. Tenor ada juga yang mengartikan the characters in the story. Menerjemahkan tenor secara benar dalam suatu teks terjemahan bisa cukup menyulitkan. Hal ini tergantung pada apakah seseorang itu memandang tingkat formalitas tertentu sebagai hal yang 'benar' dari sudut budaya sumber atau sasaran. Misal, seorang anak remaja Amerika boleh menggunakan tenor yang sangat informal dengan orangtuanya dengan menggunakan nama depan, bukan dengan panggilan ayah atau ibu.
Berdasarkan tingkat formalitas ini akan sangat tidak bisa diterima oleh kebanyak budaya lain. Seorang penerjemah harus memilih antara mengganti tenornya untuk disesuaikan dengan budaya pembaca sasaran atau tetap seperti aslinya. Hal ini tergantung apa apa yang dia lihat sebagai tujuan penerjemahan.

Tenor yang ditampilkan pada T2 cenderung mengikuti teks pada $\mathrm{T} 1$, seperti panggilan bibi dan paman pada T2 mengacu pada T1, seperti pada contoh berikut; aunt Fanny menjadi bibi Fanny, uncle Quentin menjadi paman Quentin , daddy (ayah), Timmy (Tim/Timmy), Master George menjadi Master George. Tokohtokoh yang terlibat yaitu antara lain:

- George (Georgina): Georgina adalah anak dari Bibi Fanny dan Paman Quentin, yaitu seorang anak perempuan tomboy, memiliki sifat emosional dan keras kepala.

- Julian: Julian merupakan kakak Anne dan Dick, sepupunya George. Julian seorang yang peduli dan bertanggung jawab sebagai pemimpin dari lima sekawan.

- Dick: Dick merupakan adik Julian dan kakak dari Anne. Ia suka sekali bercanda, tetapi juga teguh dan baik hati. Ia seumuran dengan sepupunya George. Dick terkenal sangat suka makan.

* Anne: Anne adalah bungsu dalam grup. Anne agak penakut dan lebih tidak suka terlibat dalam misteri dan petualangan, dan ia sering mengatakan untuk tidak lagi terlibat dalam misteri meskipun akhirnya hal itu tak terhindarkan.

* Timmy (Timothy): Timmy, kadangkadang dipanggil Tim, adalah anjing kesayangan George.

* Tokoh-tokoh lain yaitu : Bibi Fany, Paman Quentin, Orangtua Julian, Anak nelayan penjaga Tim, Penjahat dan Polisi.

Mode

Berkaitan dengan media dan jenis peran yang dimainkan bahasa (persuasive, paparan, didaktis). Misal, seperti re- adalah kata yang diterima dalam surat bisnis, tetapi sangat jarang digunakan dalam bahasa lisan. Media pada T2 yaitu sama dengan T1 sama-sama menggunakan dialog informal dengan alat saluran komunikasi (channel) yaitu sama-sama tulisan.

\section{Konteks Budaya}

Konteks budaya dalam penelitian teks dwibahasa ini dapat dilihat pada T2 yang juga 
menggunakan istilah yang sama dengan T1. Sebagai contoh, adanya budaya minum teh di sore hari di negara Inggris dijelaskan pada T2. Realisasi klausa yang mencerminkan unsur budaya di T1 tidak dihilangkan di T2. Hal ini menjadi faktor kontekstual dalam penelitian ini.

\begin{tabular}{lll}
\hline-- & Tea-time & came, \\
Akhirnya & tiba juga & saat minum teh. \\
\hline
\end{tabular}

Pada konsep genre yaitu konteks budaya juga dimediasi oleh konteks situasi. Berikut merupakan salah satu contohnya.

\begin{tabular}{lll}
\hline-- & You always & do." \\
Selama ini & Ibu selalu & bisa. \\
\hline
\end{tabular}

\begin{tabular}{ll}
\hline She & was just bringing the breakfast to the table. \\
Bibi & sedang sibuk menghidangkan sarapan. \\
Fanny & \\
\hline
\end{tabular}

Pada konteks budaya di atas, ungkapan you, she pada T1 diubah oleh penerjemah menjadi ibu dan Bibi Fanny. Hal ini mengindikasikan bahwa dalam tingkat formalitas budaya sasaran ungkapan untuk seseorang yang lebih tua atau perlu dihormati tidak dapat digunakan istilah dia, kamu.

Walaupun telah terjadi perubahan pada tenor yang berkaitan dengan konteks budaya, hal ini tidak menyebabkan terjadinya keluasan makna pada T2. Karena peran atau fungsi gramatika tetap sama antara T1 dan T2.

\section{SIMPULAN}

Berdasarkan analisis yang telah dapat ditarik kesimpulan berikut sebagai jawabanjawaban atas rumusan penelitian: (1)variasi keluasan makna tekstual sebagaimana direpresentasikan dalam satuan ungkapan gramatika tematik tema-rema yang terdapat dalam Teks Novel Five on The Treasure Island karya Enid Blyton dan Lima Sekawan di Pulau Harta karya Agus Setiadi yaitu terdapat variasi sangat rendah atau skor nol (0) dengan frekuensi 552 atau $63,52 \%$, (2)Berdasarkan hasil rerata tingkat variasi yang paling menonjol dari kedua teks tersebut, T1 muncul sejumlah 265 kali atau sebesar $55,10 \%$, akan tetapipada T2 sejumlah 216 kali atau sebesar 44,90\%. Dapat disimpulkan yaitu T1 lebih luas dari T2.

Ditinjau dari segi kebutuhan komunikatif pembaca sasaran T2 yang menginginkan penuhnya informasi, pengetahuan serta makna yang terdapat pada $\mathrm{T} 1$ ternyata tidak terealisasi di $\mathrm{T} 2$, maka kebutuhan komunikatif pembaca sasaran tidak terpenuhi.

Akan tetapi, apabila kebutuhan komunikatif pembaca sasaran T2 hanya sekedar menginginkan pengetahuan yang bersifat global dan bersifat hiburan. Hal tersebut sudah cukup terpenuhi dikarenakan kategori novel tersebut merupakan novel remaja yang target pembacanya kemungkinan adalah anak-anak hingga remaja, (3)faktor-faktor kontekstual yang memotivasi terjadinya variasi keluasan makna tekstual dalam teks dwibahasa tersebut menyangkut konteks intertekstual yang terdiri dari konteks situasional dan faktor budaya:

Konteks situasional terdiri dari field, tenor dan mode. Pada field (apa) yang dibicarakan yaitu mengisahkan tiga bersaudara yaitu Julian, Anne, Dick serta sepupu mereka bernama Georgina dan anjingnya Tim. Mereka berlima terlibat dalam kisah petualangan yang menarik.

Tenor (siapa) yang ikut andil dalam suatu cerita/pembicaraan. Menerjemahkan tenor secara benar dalam suatu teks terjemahan bisa cukup menyulitkan. Hal ini tergantung pada apakah seseorang itu memandang tingkat formalitas tertentu sebagai hal yang 'benar' dari sudut budaya sumber atau sasaran. Seorang penerjemah harus memilih antara mengganti tenornya untuk disesuaikan dengan budaya pembaca sasaran atau tetap seperti aslinya. Hal ini tergantung apa apa yang dia lihat sebagai tujuan penerjemahan. Tenor yang ditampilkan pada T2 cenderung mengikuti teks pada T1, seperti panggilan bibi dan paman pada T2 mengacu pada T1, seperti pada contoh berikut: aunt Fanny menjadi bibi Fanny, uncle Quentin menjadi paman Quentin, daddy (ayah), Timmy (Tim/Timmy), Master George menjadi Master George. Tokohtokoh yang terlibat yaitu antara lain: George (Georgina), Julian, Dick, Anne, Timmy (Timothy). Tokoh-tokoh lain yaitu: Bibi Fany, Paman Quentin, Orangtua Julian, Penjahat, dan Polisi, anak nelayan penjaga Tim.

Mode berkaitan dengan media dan jenis peran yang dimainkan bahasa (persuasive, paparan, didaktis). Misal, seperti re- adalah kata yang diterima dalam surat bisnis, tetapi sangat jarang digunakan dalam bahasa lisan. Media pada T2 yaitu sama dengan T1 sama-sama menggunakan dialog informal dengan alat saluran komunikasi (channel) yaitu sama-sama tulisan.

Konteks budaya dalam penelitian teks dwibahasa ini dapat dilihat pada T2 yang terdapat istilah budaya T1. Sebagai contoh, adanya 
budaya minum teh di sore hari di negara Inggris dijelaskan pada $\mathrm{T} 2$, walaupun dijelaskan dengan lebih luas akan tetapi tidak terlalu signifikan dalam perbedaan keluasan tema tekstual. Contoh lainnya yaitu perubahan pada ungkapan she, dan you pada T1 diubah menjadi Ibu dan Bibi Fanny, hal ini berkaitan dengan tingkat formalitas pada T2 lebih tinggi apabila berkaitan dengan seseorang yang lebih tua atau wajib dihornati. Realisasi klausa tersebut menjadi faktor kontekstual yang memotivasi terjadinya variasi nol $(\mathrm{T} 1=\mathrm{T} 2)$ karena secara fungsi atau peran gramatika ungkapan yang diubah tetap sesuai dengan $\mathrm{T} 1$.

\section{DAFTAR PUSTAKA}

Blyton, E. (1997). Five on The Treasure Island. London: Hodder Children's Books

Catford, J.C. (1965). A linguistic theory of translation. London: Oxford University Press.

Choliludin. (2005). The technique of making idiomatic translation. Bekasi Timur: Kesaint Blanc
Halliday, M.A.K. (1994). An introduction to functional grammar, second edition; London: Edward Arnolds.

Halliday, M.A.K. dan Matthiessen, Christian M.I.M. (2004). An introduction to functional grammar, revised edition. London: Arnolds.

Hatim, B \& Munday, J. (2004). Translation: an advanced resource book. Oxford: Routledge.

Munday, J. (2001). Introducing translation studies. New York: Routledge

Nida, E.T.(1982). Theory and practice of translation. Netherland :The United Bible Societies Netherland

Sinar, Tengku Silvana. (2008). Teori \& analisis wacana (pendekatan sistemik fungsional). Medan: Pustaka Bangsa Press 